\title{
Sistem Informasi Penentuan Guru Terbaik Berbasis Kinerja pada Pondok Pesantren Qodratullah
}

\author{
Andri $^{1}$, Suyanto ${ }^{2}$ \\ ${ }^{1,2}$ Program Studi Sitem Informasi, Fakultas Ilmu Komputer, Universitas Bina Darma \\ ${ }^{1,2}$ Jl. Jendral Ahmad Yani No 3 Seberang Ulu I Palembang, Indonesia 30264 \\ e-mail: ${ }^{1}$ andri@ binadarma.ac.id, ${ }^{2}$ suyanto@binadarma.ac.id
}

\begin{abstract}
Abstrak
Pengukuran kinerja merupakan salah satu tolak ukur untuk melihat bagaimana seseorang dalam melakukan pekerjaannya. Untuk melakukan pengukuran kinerja banyak cara yang dapat dilakukan baik secara konvensional ataupun terkomputerisasi. Pengukuran kinerja sendiri saat ini telah masuk disemua lini baik pemerintahan, industri maupun pendidikan. Pondok Pesantren Qodratullah merupakan lembaga Pendidikan yang mengedepankan Pendidikan agama islam dalam proses pembelajarannya. Saat ini Pondok Pesantren Qodratullah telah melakukan penilaian untuk menentukan guru terbaik. Namun dalam proses penilaian mulai dari pembuatan form penilaian, pengisian penilaian, dan rekapitulasi hasil penilaian yang membutuhkan waktu dan tenaga yang tidak sedikit. Sesuai dengan kondisi tersebut maka penelitian ini dilakukan pengembangan sistem informasi untuk menentukan guru terbaik sebagai upaya memudahkan proses penilaian. Metode pengembangan digunakan yaitu prototype dengan tiga tahapan pengembangan. Hasil dari penelitian berupa sistem informasi penentuan guru terbaik yang memiliki fitur mulai dari penentuan kriteria, sub kriteria, indikator, guru, proses penilaian guru dan pelaporan hasil penilaian.
\end{abstract}

Kata kunci: sistem informasi, guru terbaik, kinerja, prototype

\begin{abstract}
Performance measurement is one of the benchmarks to see how someone is doing their work. To measure the performance of many ways that can be done either conventionally or computerized. Performance measurement itself is now included in all lines of government, industry and education. Qodratullah Islamic Boarding School is an educational institution that emphasizes Islamic religious education in the learning process. Currently Qodratullah Islamic Boarding School has conducted an assessment to determine the best teacher. But in the appraisal process starting from making an appraisal form, filling in the appraisal, and recapitulating the results of the appraisal that requires a lot of time and effort. In accordance with these conditions, this research was carried out the development of information systems to determine the best teacher in an effort to facilitate the assessment process. The development method used is prototype with three stages of development. The results of the study are in the form of an information system for determining the best teachers who have features ranging from determining criteria, sub criteria, indicators, teachers, teacher assessment process and reporting on assessment results.
\end{abstract}

Keywords: information system, best teacher, performance, prototype.

\section{Pendahuluan}

Pendidikan di Indoensia adalah salah satu sektor penting yang diatur secara khusus melalui undang-undang, bahkan pendidikan sendiri memiliki anggaran yang sangat besar yaitu 
dua puluh persen dari total anggaran pendapatan dan belanja negara [1]. Jenis pendidikan di Indonesia diantaranya pendidikan umum dan pendidikan agama [2]. Pendidikan merupakan hal terpenting dalam setiap bidang kehidupan, hal ini dikarenakan pendidikan merupakan sarana dalam menyalurkan pengetahuan agar mampu membentuk karakter setiap individu serta menjadikan kehidupannya menjadi lebih baik dan berpendidikan. Di dalam dunia Pendidikan, guru memiliki peran yang sangat penting dalam memajukan pendidikan di sekolah terutama peserta didik. Guru berperan dalam mengajarkan, mendidik, membentuk sifat atau karakter, mengarahkan, menilai serta mengevaluasi para peserta didik [3].

Pondok Pesantren Qodratullah (PPQ) merupakan salah satu Pesantren yang ada di Provinsi Sumatera Selatan. Sejauh ini PPQ memiliki santri dari berbagai daerah di Indoensia bahkan dari luar negeri. Sistem pendidikan yang ada pada PPQ sama seperti lembaga pendidikan lainnya, namun terdapat penambahan kurikulum agama islam yang sangat menonjol. Saat ini PPQ memiliki tingkatan pendidikan mulai dari Madrasah Ibtidaiyah, Madrasah Tsanawiyah dan Madrasah Aliyah. Pada setiap tingkatan terdapat guru yang dikenal dengan Ustad dan Ustadzah sebagai pengasuh dan pendidik, baik dalam kehidupan sehari-hari maupun di lingkungan kelas belajar mengajar. Setiap tahunnya PPQ memilih Ustad dan Ustadzah (guru) terbaik atau berprestasi untuk setiap tingkatan. Kondisi tersebut dilakukan untuk memberikan motivasi bagi guru agar memberikan yang terbaik dalam proses belajar mengajar [4].

Guru yang berprestasi merupakan guru yang memiliki keunggulan, mempunyai nilai komparatif yang baik dibandingkan guru yang lain dalam konteks atau lingkup pembelajaran dan Pendidikan. Maksud diadakannya pemilihan guru yang berprestasi adalah untuk meningkatkan kemampuan profesionalisme guru, baik berupa motivasi individu guru serta dedikasi maupun loyalitas terhadap sekolah dan peserta didik yang diharapkan mampu mengarah kepada peningkatan kualitas dan mutu serta kualitas guru dalam mendidik para peserta didik agar peserta didik lebih berkualitas, produktif serta kompetitif. Maka dari pada itu diperlukan suatu proses pemilihan guru berprestasi guna meningkatkan motivasi guru serta profesionalisme guru berbasis sistem informasi.

Kajian dalam menentukan guru berprestasi atau guru terbaik sebenarnya telah banyak dilakukan diantaranya yang di lakukan pada SMP Islam Al Hikmah, dimana dalam proses penentunan guru terbaik dilakukan menggunakan sebuah motode yaitu Analytical Hierarchy Process dengan empat kriteria penilaian yaitu presensi, ketertiban, kesopanan dan profesional [5]. Kajian lain juga dilakukan pada Yayasan Lentera Insan, dimana dalam kajian ini dilakukan pemilihan guru terbaik berbasis kinerja menggunakan metode yang digunakan sama yaitu Analytical Hierarchy Process dengan lima belas kriteria penilaian [6]. Selain dua kajian tersebut terdapat juga kajian lain yaitu yang dilakukan pada MA AL Mubarok Batu Raja, di dalam kajian ini metode yang digunakan yaitu metode TOPSIS. Kriteria penilaian terdiri dari penguasaan bahasa asing, presensi, penilaian sejawat, penilaian siswa, kualitas dalam mengajar, psikotes, interaksi dengan siswa dan sikap di luar sekolah [7]. Dari semua proses penilaian untuk menentukan guru terbaik tersebut belum ada kriteria berkaitan secara spesifik dengan guru dalam proses belajar mengajar yaitu pedagogik, sosial, profesional dan kepribadian. Untuk itu di dalam penelitian akan dilakukan pengembangan sistem informasi untuk menentukan guru terbaik di Pondok Pesantren Qodratullah dengan menerapkan kriteria penilaian pedagogik, sosial, profesional dan kepribadian.

\section{Metode Penelitian}

Metode penelitian yang digunakan untuk menjelaskan hasil penelitian yaitu metode deskriptif. Metode deskriptif digunakan banyak peneliti untuk menjelaskan atau menjabarkan hasil penelitian berdasarkan kejadian atau fakra yang dialami oleh peneliti. Metode deskriptif juga dapat digunakan untuk menjelaskan fenomena sesuai dengan prosedur ilmiah yang aktual 
sebagai penjabaran dari pemecahan dan jawaban terhadap sebuah permasalahan yang diteliti oleh peneliti [8]. Sehingga penggunaan metode deskriptif dalam menjelaskan hasil penelitian pengembangan sistem informasi penentuan guru terbaik berbasis kinerja pada Pondok Pesantren Qodratullah sangat tepat untuk digunakan. Selain metode deskriptif untuk menjelaskan hasil penelitian digunakan juga metode perhitungan untuk menentukan guru terbaik. Metode yang digunakan yaitu perhitungan berbasis kinerja yang terdiri dari pedagogik, sosial, profesional dan kepribadian menggunakan metode 360 derajat.

\subsection{Metode Pengembangan Sistem Informasi}

Dalam proses pengembangan sistem informasi untuk penentuan guru terbaik berbasis kinerja pada Pondok Pesantren Qodratullah maka metode pengembangan yang digunakan adalah metode prototype. Metode prototype merupakan metode pengembangan yang mengedepankan keterlibatan pengguna dalam proses pengembangan. Pengguna selalu berinteraksi dalam proses pengembangan mulai dari penentuan kebutuhan sistem informasi hingga fase akhir pengembangan sistem informasi [9]. Secara umum metode prototype memiliki proses pengerjaan dimulai dari pengumpulan kebutuhan, fase ini biasaya pengembang dan pengguna sistem informasi menentukan kebuthuan dari sistem informasi yang akan dibuat [10]. Kebtuhan tersebut meliputi modul sistem informasi dan kebutuhan bentuk dan proses yang diinginkan [11]. Setelah diketahui kebutuhan maka dilanjutkan dengan melakukan perancangan, fase ini dibuat perancangan sistem informasi mulai dari rancangan proses dan rancangan antarmuka. Rancangan proses biasaya dibuat menggunakan diagram unified modeling language, sedangkan rancangan antarmuka dibuat menggunakan melalui aplikasi atau prototype dari sistem informasi secara langsung. Langkah terakhir adalah melakukan evaluasi dari perancangan atau prototype yang dihasilkan, fase ini adalah fase dimana pengguna memberikan masukkan terhadap sistem informasi yang dihasilkan. Jika hasil prototype dirasa perlu perbaikan maka pengembang akan melakukan perbaikan, kondisi tersebut terus berlajalan secara iterative hingga sistem informasi dianggap sempurna oleh pengguna. Proses pengembangan dengan metode prototype sendiri seperti yang diilustrasikan pada Gambar 1 [12].

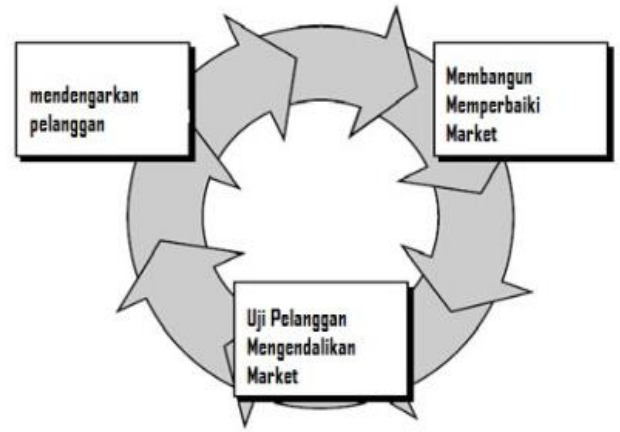

\section{Hasil dan Pembahasan}

Gambar 1. Proses pengembangan dengan prototype

Hasil penelitian berupa sistem informasi penentuan guru terbaik berbasis kinerja pada Pondok Pesantren Qodratullah. Dalam menenetukan guru terbaik digunakan metode 360 derajat dengan empat kriteria utama yaitu pedagogik, sosial, profesional dan kepribadian. Perbedaan penelitian ini yaitu terletak pada kriteria penelitian yang berjumlah empat kriteria, kondisi tersebut dapat dilihat dari penelitian lain yang menggunakan lima belas kriteria [6], ada juga menggunakan sembilan belas kriteria [13], lima kriteria [14] atau bahkan lebih sedikit yaitu tiga kriteria [15]. Sedangkan yang menjadi penilai dalam proses penentuan guru terbaik terdiri dari unsur atasan, teman sejawat dan siswa atau satri. Dengan demikian proses penilaian telah memenuhi semua pihak yang terlibat dalam menentukan guru (ustad/ustazah) terbaik di 
lingkungan Pondok Pesantren Qodratullah. Proses penentuan guru terbaik mengalami perubahan ketika adanya sistem informasi yang telah dihasilkan. Perubahan yang signifikan yaitu ketika melakukan pendataan nilai bagi guru, dimana selama ini proses dilakukan pada kertas yang dibagikan untuk setiap guru dan guru terebut harus mendapatkan penilaian dari unsur atasan, sejawat dan siswa dan mengumpulkan kembali ke pihak penilai. Adanya sistem informasi membuat proses menjadi lebih mudah dilakukan dengan cara mengisi penilaian melalui komputer yang tersedia pada laboratorium Pondok Pesantren Qodratullah. Secara umum komponen sistem informasi telah berjalan dengan baik sesuai dengan pengujian black box yang telah dilakukan seperti yang diperlihatkan pada Tabel 1.

Tabel 1. Hasil Pengujian

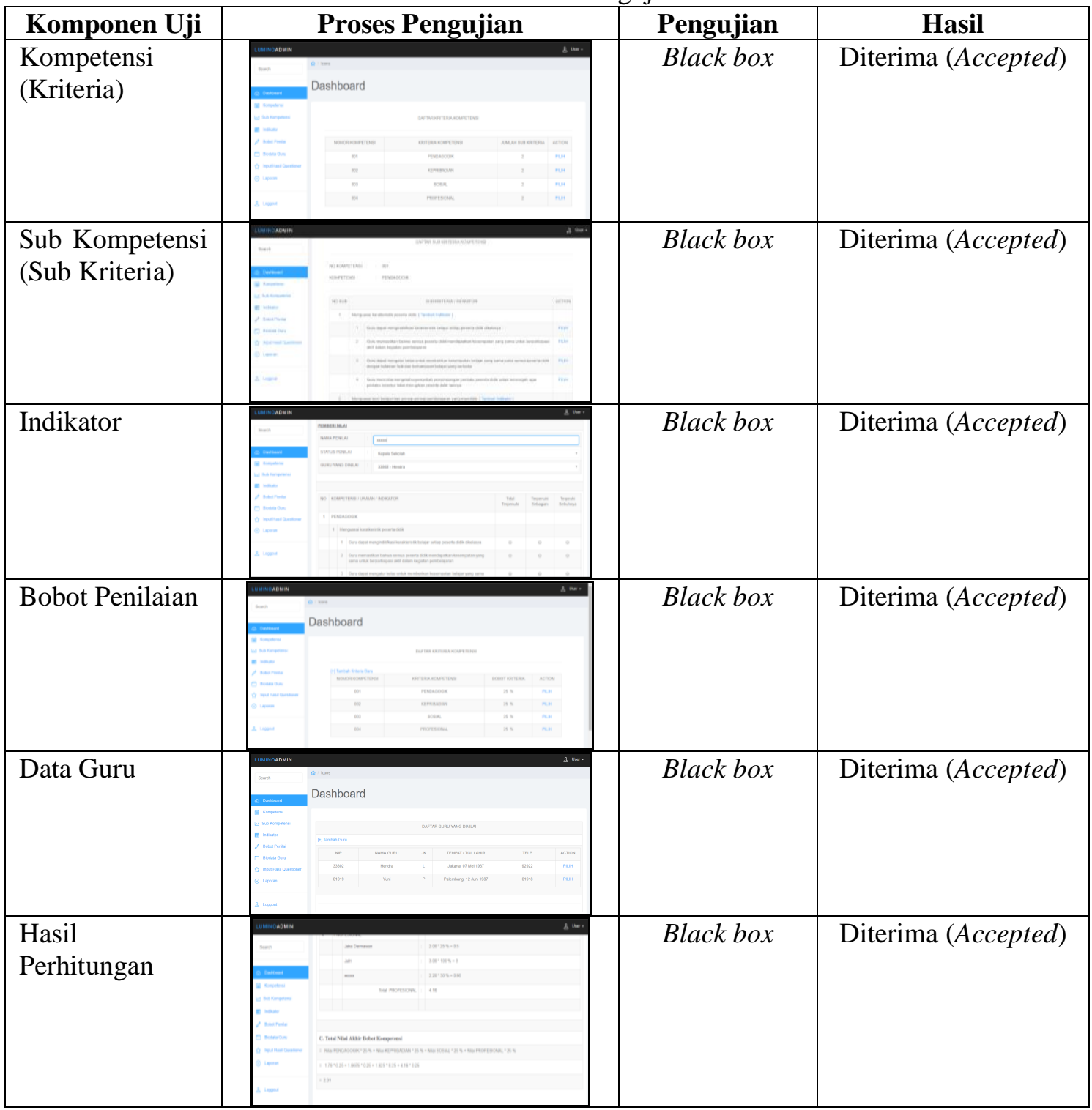

Sistem informasi ini memiliki berbagai fitur sebagai interkasi pengguna untuk melakukan aktivitas. Gambar 2 dapat dilihat merupakan use case diagram merupakan salah satu diagram yang ada pada unified modeling language (UML). Use case diagram merupakan diagram yang menggambarkan bagaimana fungsional atau fitur yang ada pada sistem informasi berhubungan dengan pengguna. Use case diagram juga dapat dikatakan sebagai diagram yang memiliki 
kemampuan untuk melihat sistem informasi memberikan layanan terhadap pengguna [16]. Sesuai Gambar 2 dapat diketahui aktivitas, fitur atau layanan yang ada terdiri dari melakukan input kompetensi (kriteria) yang terdiri dari pedagogik, sosial, profesional dan kepribadian, input sub kopetensi (sub kriteria) yang terdiri dari mengenal karakteristik peserta didik, menguasai teori belajar dan prinsip-prinsip pembelajaran yang mendidik, pengembangan kurikulum, kegiatan pembelajaran yang mendidik, memahami dan mengembangkan potensi, komunikasi dengan peserta didik, penilaian dan evaluasi untuk kriteria pedagogik. bertindak sesuai dengan norma agama, hukum, sosial dan kebudayaannasional indonesia, menunjukkan pribadi yang dewasa dan teladan, etos kerja, tanggung jawab yang tinggi, rasa bangga menjadi guru untuk kriteria kepribadian. Bersikap inklusif, bertindak obyektif, serta tidak diskriminatif, guru, tenaga kependidikan, orang tuapeserta didik, dan masyarakat adalah untuk kriteria sosial. terakhir Penguasaan materi struktur konsep dan pola pikir keilmuan yang mendukung mata pelajaran yang diampu, Mengembangkan keprofesian melalui tindakan reflektif untuk kriteria professional. Input indikator, penentuan bobot penilaianan, input data guru dan input hasil kuesioner sesuai dengan indikator.

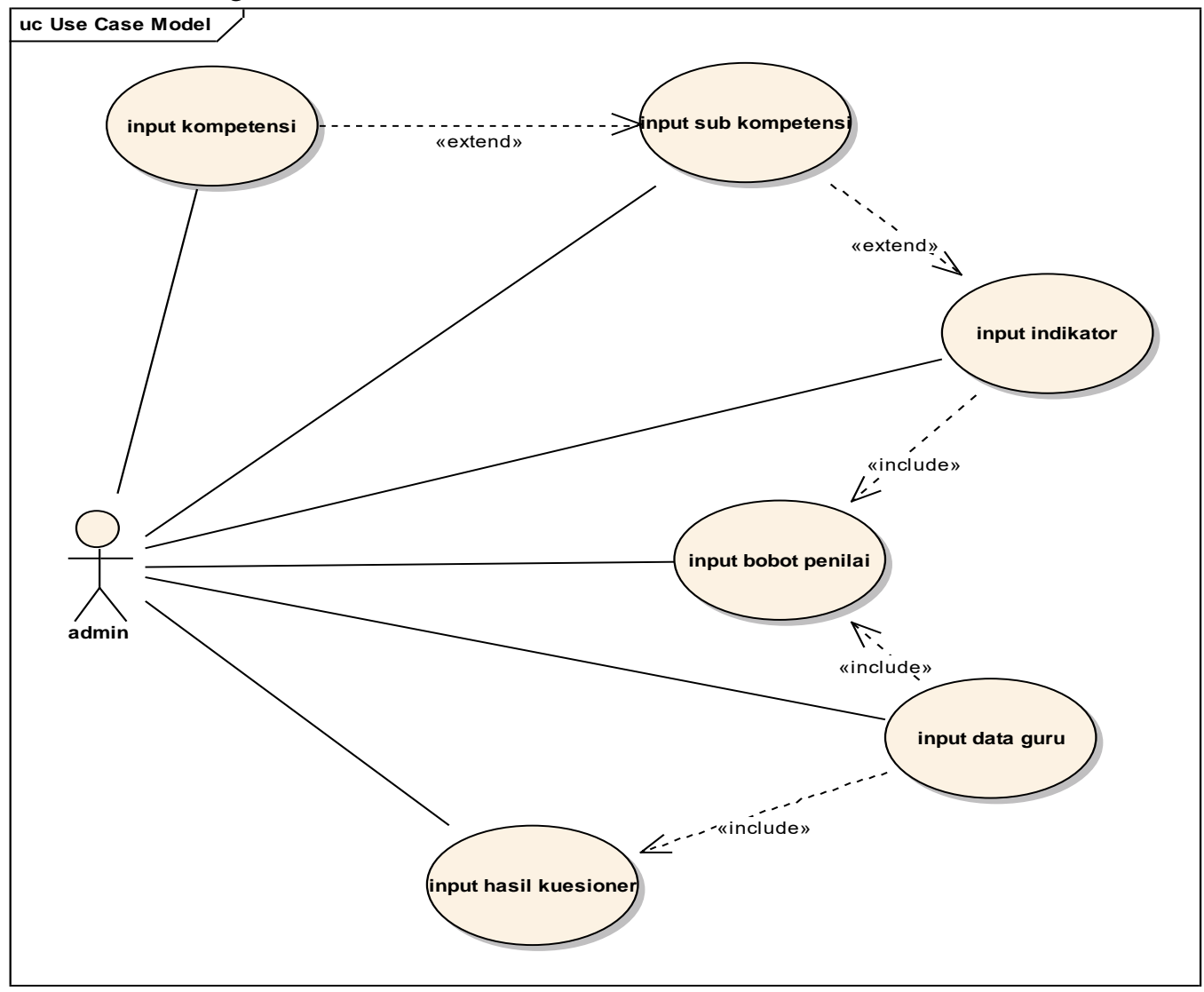

Gambar 2. Use case diagram sistem informasi

Setelah mengetahui bagaimana aktivitas, fitur atau layanan dari sistem informasi penentuan guru terbaik berbasis kinerja pada Pondok Pesantren Qodratullah maka dilakukan perancangan antarmuka. Gambar 3 merupakan adalah rancangan antarmuka untuk melakukan input kompetensi (kriteria) penilaian. Untuk menetukan besaran dari masing-masing bobot kriteria maka dapat dilakukan dengan cara persentase. Dimana total dari semua kriteria harus berjumlah seratus persen (100\%) [17]. 


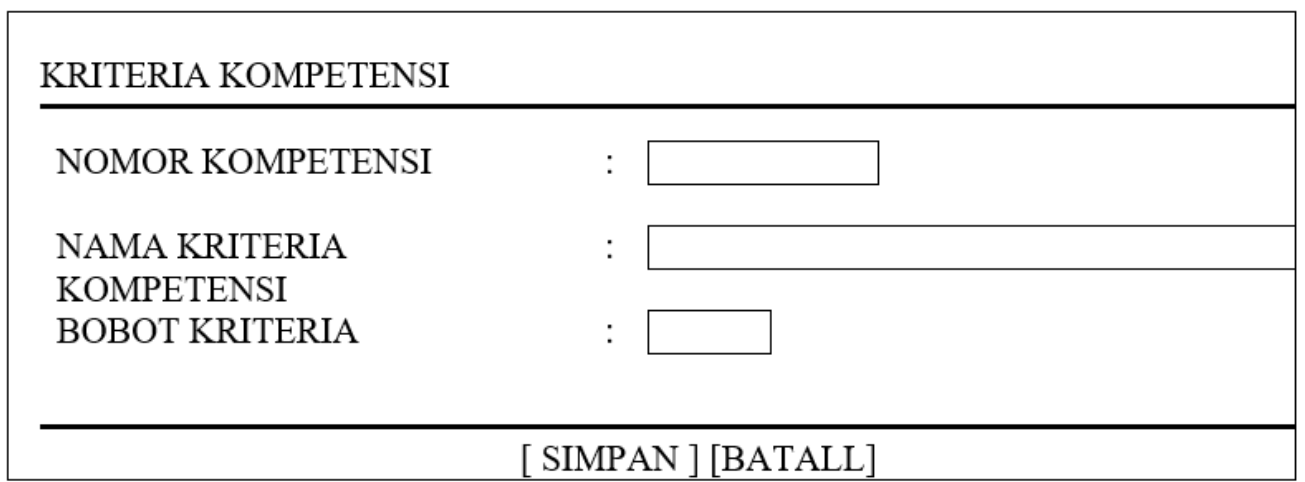

Gambar 3. Perancangan input kompetensi (kriteria)

Selain perancangan input kompetensi (kriteria) juga dibuat perancangan beberapa antarmuka yang lain, seperti yang diperlihatkan pada Gambar 4. Gambar 4 merupakan perancangan antarmuka unutk menentukan bobot untuk masing-masing kriteria.

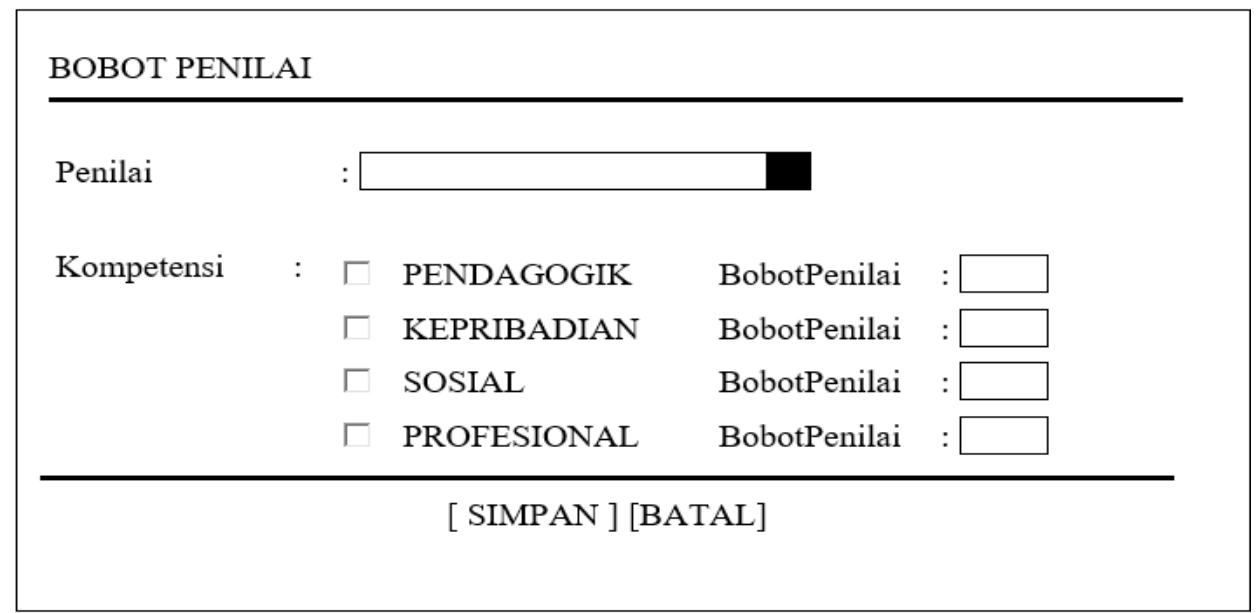

Gambar 4. Penentuan bobot penilaian kompetensi (kriteria)

Berdasarkan tahapan dari metode prototype maka setelah proses pengumpulan kebutuhan yang dapat dilihat dari perancangan dilakukan proses pembuatan prototype sistem informasi. pembuatan prototype sistem informasi dilakukan perbaikan jika pengguna mengangap belum memenuhi kebutuhan. Setelah prototype sistem informasi dianggap sempurna maka proses pengembangan sistem informasi diaggap selesai. Untuk itu berikut dapat dijelaskan sistem informasi penentuan guru terbaik berbasis kinerja pada Pondok Pesantren Qodratullah yang dihasilkan sesuai proses pengembangan.

Gambar 5 merupakan tampilan halaman utama dari sistem informasi penentuan guru terbaik berbasis kinerja pada Pondok Pesantren Qodratullah setelah pengguna melakukan login. Pada halaman utama ini terdapat beberapa menu yang dapat digunakan oleh pengguna untuk melakukan proses penilaian penentuan guru terbaik. Menu tersebut meliputi kompetensi (kriteria), sub kopetensi (sub kriteria), indikator, bobot penilaian, guru, proses input hasil kuesioner dan laporan hasil penilaian. Untuk menentukan proses peneilaian maka dilakukan penentuan bobot kriteria dalam bentuk pesentase penilaian. Untuk menentukan bobot kriteria maka dapat dilakukan pada menu bobot penilaian seperti yang diperlihatkan pada Gambar 6 . Dalam perhitungan penentuan guru terbaik ini digunakan metode perhitungan 360 derajat. Dimana Untuk menghitung penilaian 360 Derajat, menggunaan rumus sebagai berikut [18]: 


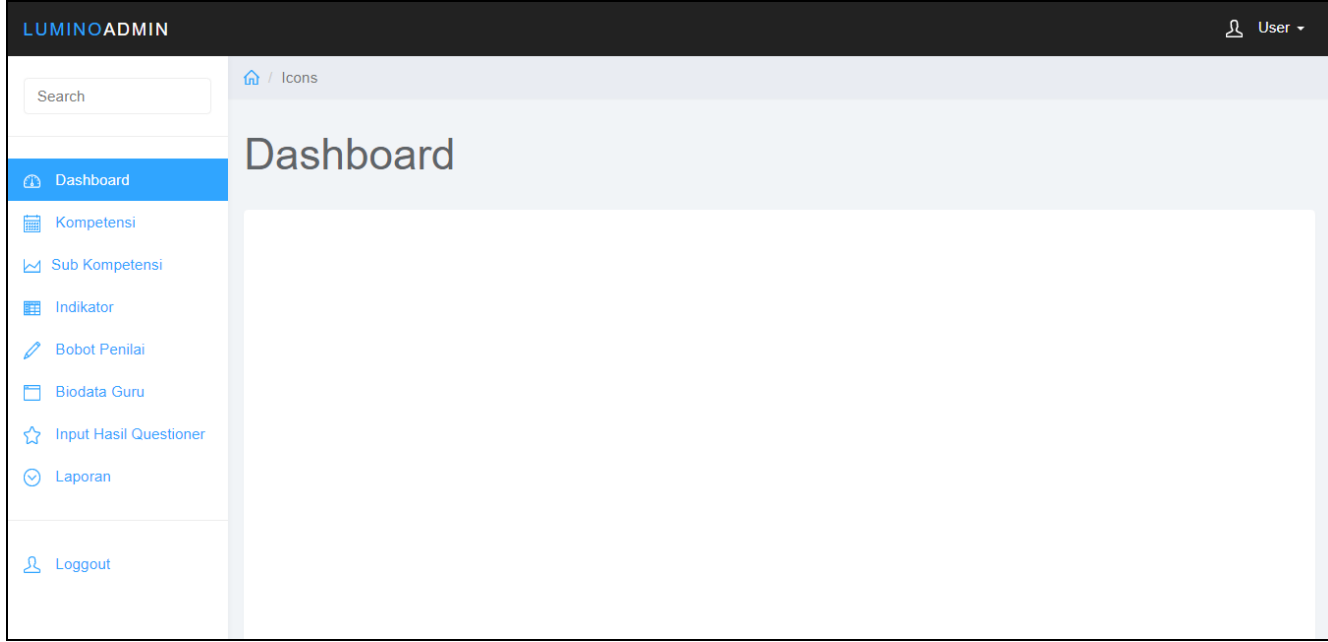

Gambar 5. Halaman utama sistem informasi

a. Menggunakan Penilai 1

Dimana :

$$
\begin{aligned}
\text { Nilai Kriteria }_{i} & =\sum_{\substack{j=1\\
}}^{n}\left(\text { Nilai Subkriteria }_{i j}\right. \\
& \left.* \text { bobot }_{i j}\right)
\end{aligned}
$$

Nilai Kriteria ${ }_{\mathrm{i}}=$ total nilai subkriteria ke-i

Nilai Subkriteria $_{\mathrm{ij}}=$ nilai subkriteria dari kriteria ke-i pada bobot ke-j

Bobot $_{\mathrm{ij}}=$ tingkat kepentingan (bobot) kriteria ke-j

$\mathrm{I}=1,2,3 \ldots \mathrm{n} ; \mathrm{n}=$ jumlah kriteria

$\mathrm{j}=1,2,3 \ldots \mathrm{m} ; \mathrm{m}=$ jumlah bobot

b. Menggunakan Penilai 2

$$
\begin{aligned}
& =\sum_{j=0}^{\text {Nilai Kriteria }_{i}}\left\{\sum_{k=1}^{n}\left(\text { Nilai Subkriteria }_{i k} * \text { bobot }_{i k}\right)\right\}
\end{aligned}
$$

Dimana:

Nilai Kriteria ${ }_{i}=$ total nilai subkriteria ke-i

Nilai Subkriteria $_{\mathrm{ik}}=$ nilai subkriteria dari kriteria ke-i pada bobot ke-k

Bobot $_{\mathrm{ik}}=$ tingkat kepentingan (bobot) kriteria ke-k

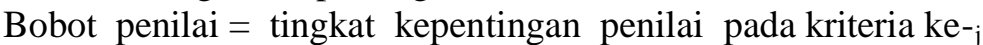

$\mathrm{I}=1,2,3 \ldots \mathrm{n} ; \mathrm{n}=$ jumlah kriteria

$\mathrm{j}=1,2,3 \ldots \mathrm{m} ; \mathrm{m}=$ jumlah bobot penilai

$\mathrm{k}=1,2,3 \ldots \mathrm{m} ; \mathrm{m}=$ jumlah bobot

c. Nilai Akhir

$$
\begin{aligned}
& \text { Nilai Akhir Penilaian } \\
& \qquad=\sum_{i=1}^{n} \text { Nilai Kriteria }_{i}
\end{aligned}
$$


Dimana:

Nilai Akhir Penilaian= total nilai dari kriteria ke-i

Nilai Kriteria $a_{\mathrm{i}}=$ nilai dari kriteria ke-i

$\mathrm{I}=1,2,3 \ldots \mathrm{n} ; \mathrm{n}=$ jumlah kriteria.

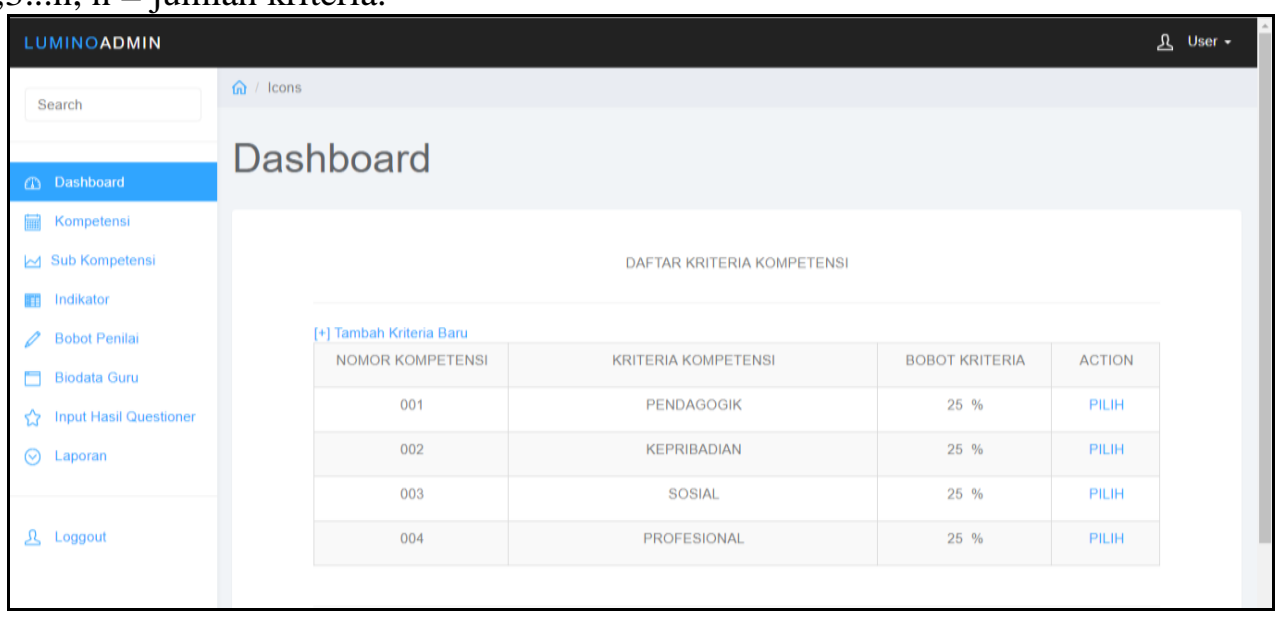

Gambar 6. Daftar kriteria kompetensi penilaian

Sebelum menentukan bobot kompetensi (kriteria) seperti yang diperlihatkan pada Gambar 6 maka proses yang harus dilakukan adalah melakukan input data kompetensi (kriteria) untuk melakukan penentuan guru terbaik. Untuk melakukan input kompetensi (kriteria) penelian dapat digunakan menu kompetensi. Setelah data data kompetensi (kriteria) telah maka proses selanjutnya adalah menambahkan data sub kompetensi (sub kriteria) seperti yang diperlihatkan pada Gambar 7.

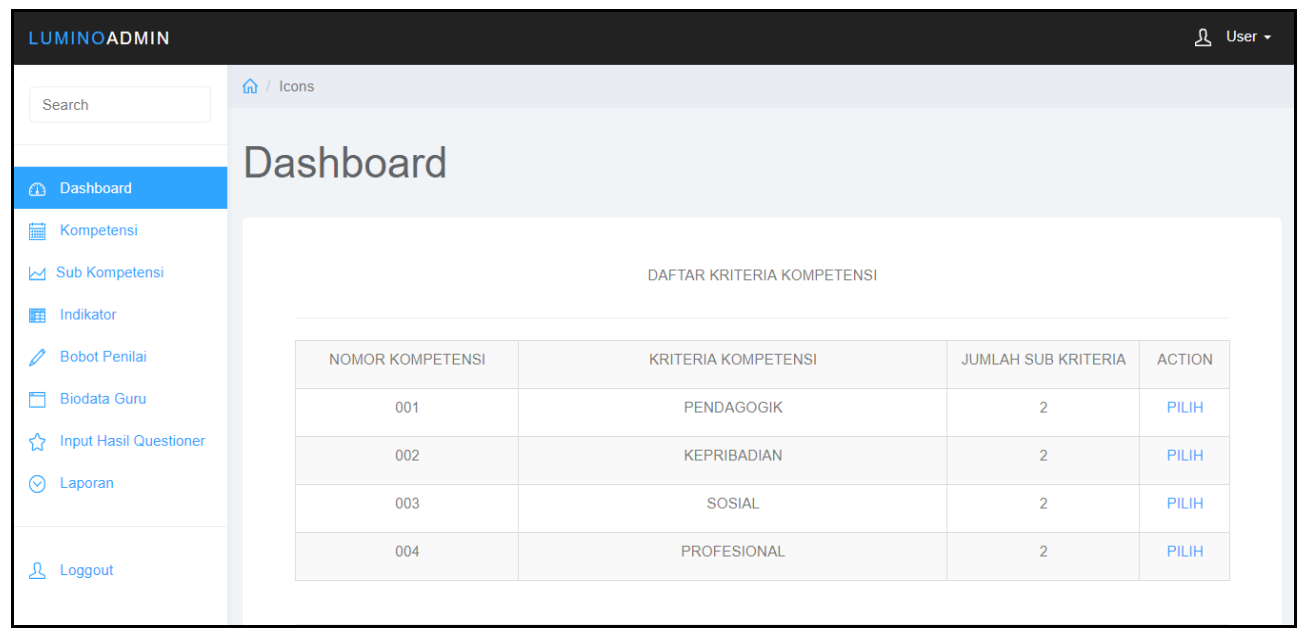

Gambar 7. Daftar kriteria dan jumlah sub kriteria penilaian

Proses selanjutnya adalah memberikan indikator penialaian untuk masing-masing sub kompetensi (kriteria) yang telah dibuat. Indikator dibuat dalam bentuk pernyataan yang akan dinilai. Pernyataan untuk masing-masing indikator dapat disesuaikan dari tim penilai. Setiap indikator akan dijawab oleh penilai dengan memilih jawaban tidak terpenuhi, terpenuhi sebagian dan terpenuhi seluruhnya. Gambar 8 dapat dilihat merupakan daftar dari indikator yang ada pada sistem informasi penentuan guru terbaik berbasis kinerja pada Pondok Pesantren Qodratullah. 


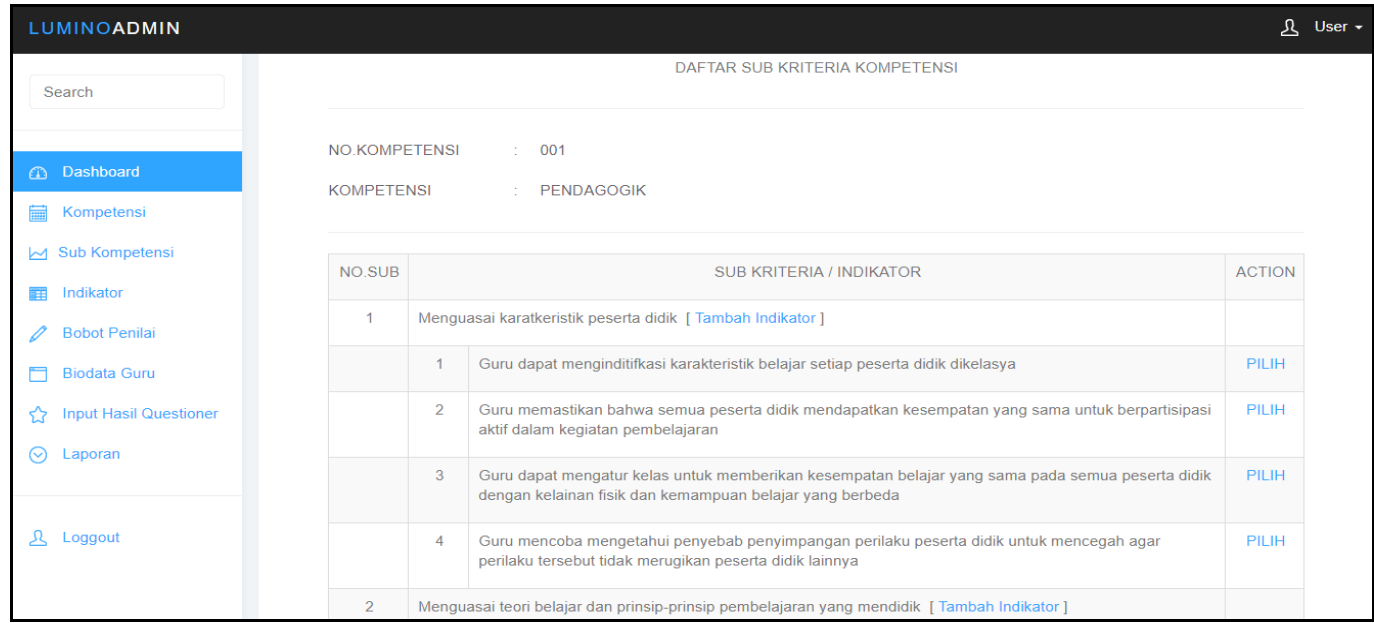

Gambar 8. Daftar indikator penilaian

Untuk melakukan penilaian dalam melakukan penentuan guru terbaik maka data yang diperlukan juga yaitu data guru. Data guru merupakan data yang menjadi objek penilaian yang terdiri dari nip, nama guru, jenis kelamin, tempat lahir, tanggal lahir da nomor telepon. Proses pengelolaan data guru dapat dilakukan melalui menu biodata guru yang terdapat pada sistem informasi penentuan guru terbaik berbasis kinerja pada Pondok Pesantren Qodratullah seperti yang terlihat pada Gambar 9.

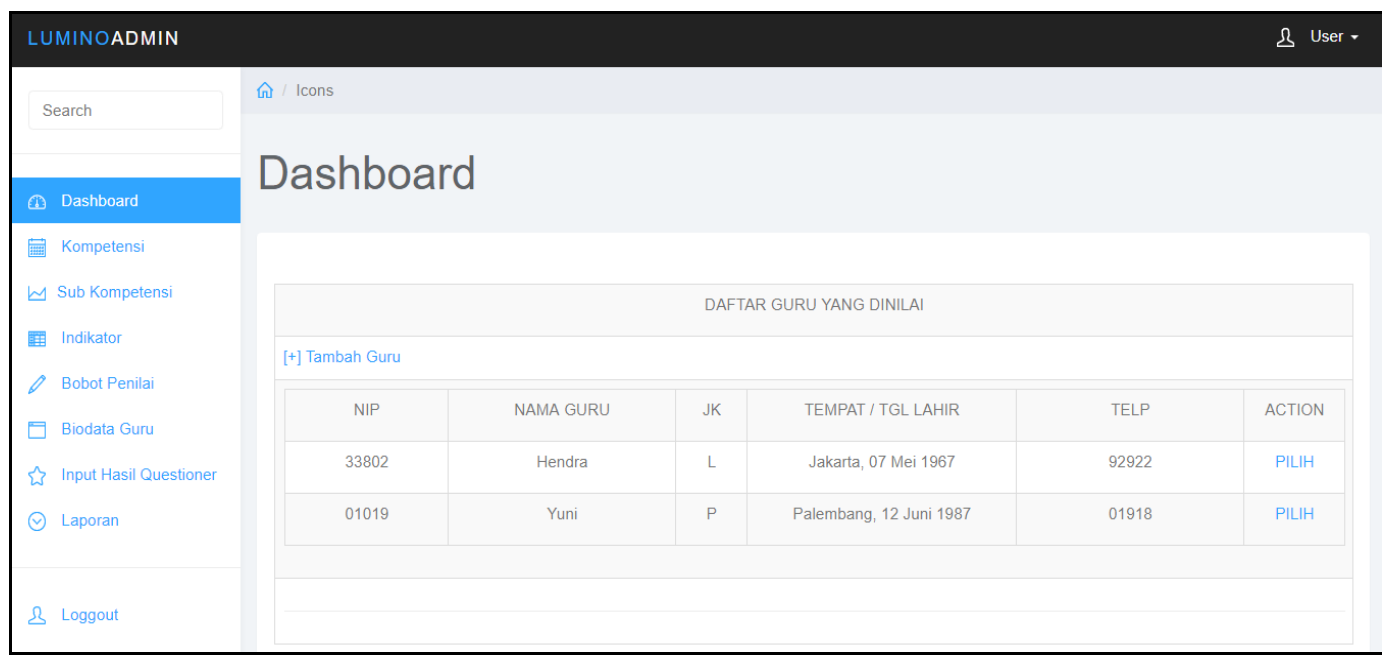

Gambar 9. Pengelolaan data guru

Setelah diketehui data guru yang akan dinilai seperti yang diperlihatkan pada Gambar 9 maka selanjutnya adalah proses penilaian. Proses penilaian dilakukan oleh tim penilai. Dalam melakukan penilaian disediakan pernyataan yang dikelompokkan berdasarkan kompetensi (kriteria) dan sub kompetensi (sub kriteria). Pernyataan yang diberikan dapat dijawab oleh penilai dengan jawaban tidak terpenuhi, terpenuhi sebagian dan terpenuhi semuanya. Jawaban yang diberikan akan di konversi ke dalam bentuk angka skala linkert yang terdiri dari 1 berarti tidak terpenuhi, 2 berarti terpenuhi sebagian, dan 3 terpenuhi semuanya. Sedangkan yang berhak memberikan penilaian terhadap guru (ustad dan ustazah) adalah atasan dan teman 
sejawat dalam kegiatan proses belajar mengajar. Gambar 10 merupakan salah satu proses penilaian dalam penentuan guru terbaik pada Pondok Pesantren Qodratullah.

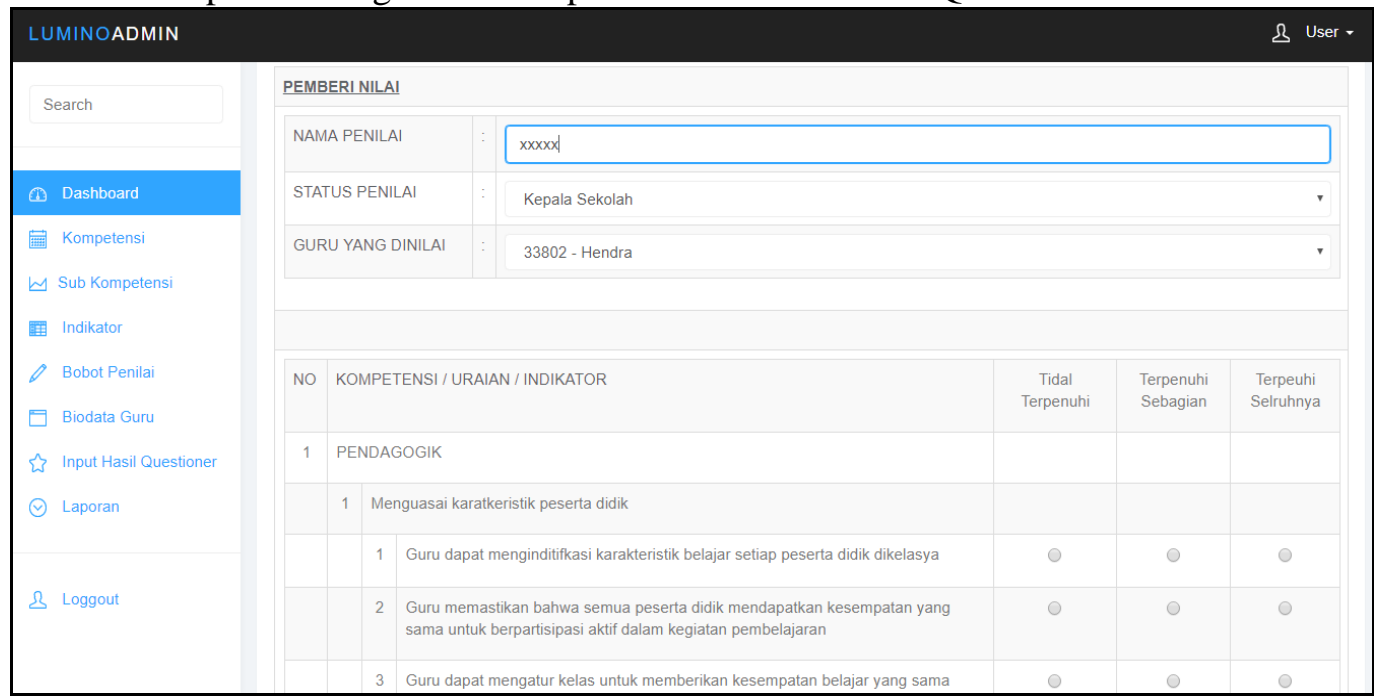

Gambar 10. Proses penilaian guru

Setelah proses penilaian selesai maka akan tampil hasil penilaian dan diurutkan berdasarkan nilai terbesar sampai dengan terkecil. Untuk melihat hasil penilaian dapat dilakukan melalui menu laporan. Setelah menu laporan di klik maka otomatis hasil penilaian akan ditampilkan seperti yang diperlihatkan pada Gambar 11.

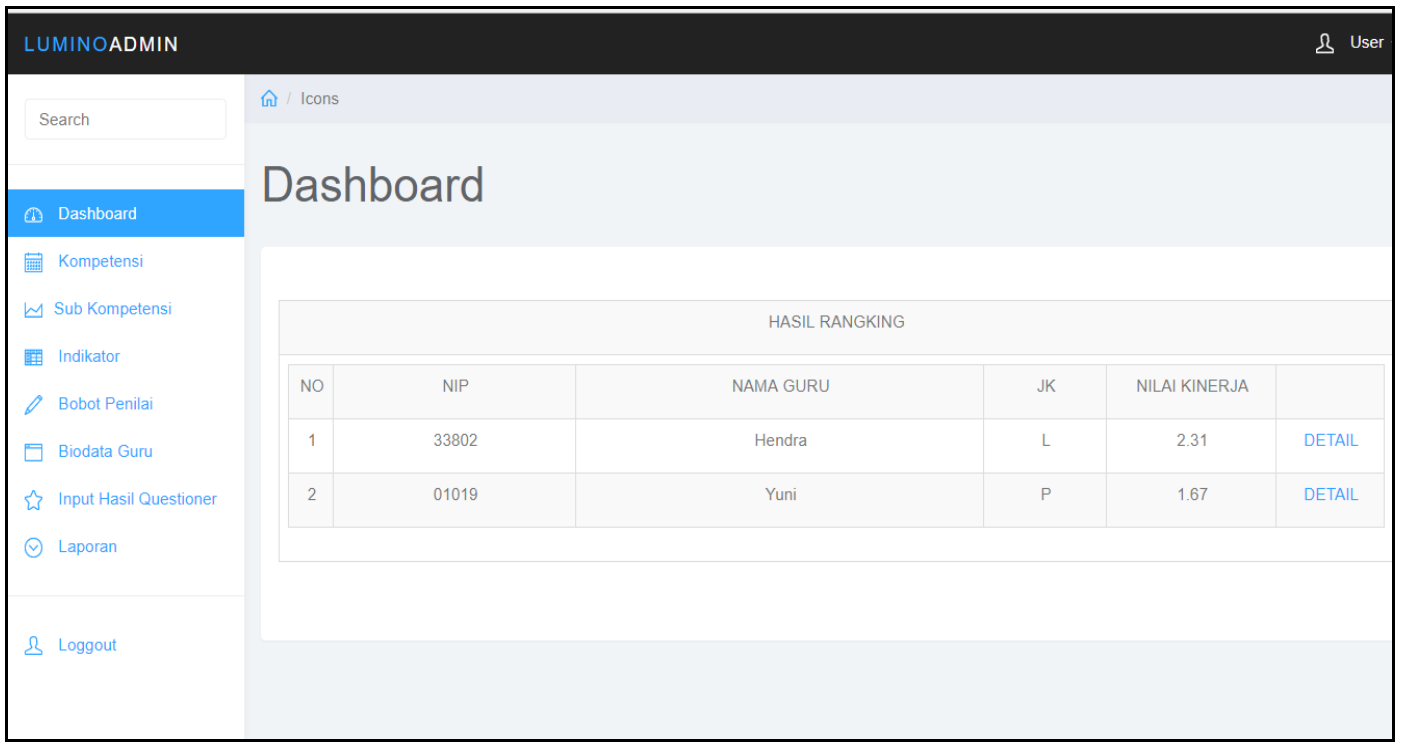

Gambar 11. Laporan rangking penilaian

Untuk melihat nilai yang diberikan pada masing-masing guru maka dapat dilakukan melalui menu detail. Setelah menu detail diklik maka akan ditampilkan semua penilaian yang diberikan oleh atasan maupun teman sejawat yang dikelompokkan berdasarkan kompetensi (kriteria) penilaian yang terdiri dari pedagogik, sosial, profesional dan kepribadian. Gambar 12 dapat dilihat detail dari perhitungan untuk setiap kompetensi (kriteria) yang ada pada sistem informasi penentuan guru terbaik berbasis kinerja pada Pondok Pesantren Qodratullah. 


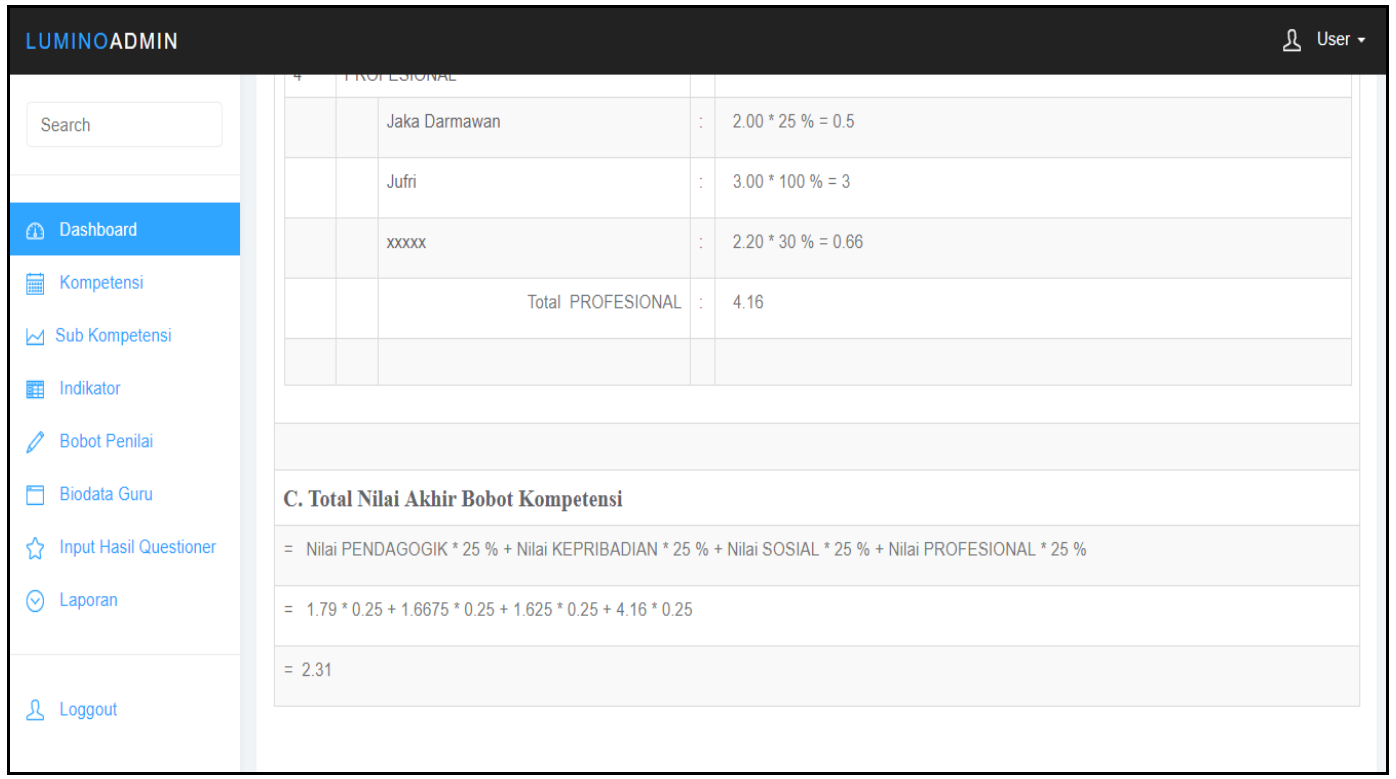

Gambar 12. Detail perhitungan penilaian

\section{Kesimpulan}

Sesuai dengan uraian yang telah dikemukakan dan proses penelitian yang maka dapat disimpulkan beberapa hal yaitu: Proses pengembangan sistem informasi penentuan guru terbaik berbasis kinerja pada Pondok Pesantren Qodratullah telah dilakukan menggunakan metode prototype yang terdiri dari tiga tahapan utama yaitu mendengarkan pelangan (pengumpulan kebutuhan), membuat prototype sistem informasi, dan evaluasi prototype sistem informasi dilakukan dengan konsultasi ke pihak Pondok Pesantren Qodratullah. Sistem informasi penentuan guru terbaik berbasis kinerja pada Pondok Pesantren Qodratullah yang dihasilkan dapat menjalankan proses penilaian untuk menentukan guru terbaik dibuktikan dengan menu dan antamuka yang diterdapat pada sistem informasi. Hasil penialain dapat dilihat secara cepat dan dapat ditampilkan berurutan sesuai rangkin nilai guru (ustad/ustazah).

\section{Daftar Pustaka}

[1] M. Anggraeni, "Analisis Pengaruh Pengeluaran Pemerintah di Sektor Pendidikan, Kesehatan, dan Pertanian terhadap Pertumbuhan Ekonomi Indonesia Periode 19702015," J. Pendidik. dan Ekon., vol. 6, no. 5, pp. 499-509, 2017.

[2] P. R. INDONESIA, "Peraturan Pemerintah Republik Indonesia Nomor 55 Tahun 2007 tentang Pendidikan Agama dan Pendidikan Keagamaan," Jakarta Sekr. Negara. Diakses tanggal, vol. 12, 2017.

[3] A. Setiawan, "Peran keterampilan menulis dalam meningkatkan profesionalitas guru di era society 5.0," in Prosiding Seminar Nasional Bahasa dan Sastra Indonesia (SENASBASA), 2019, vol. 3, no. 2.

[4] M. A. Qodratullah, "Pforifil Pondok Pesantren Qodratullah," 2020.

[5] N. B. Wibowo and D. Anubhakti, "sistem informasi penunjang keputusan penentuan guru terbaik pada sekolah smp islam al hikmah dengan metode analytical hierarchy process (ahp)," IDEALIS Indones. J. Inf. Syst., vol. 3, no. 1, pp. 486-491, 2020.

[6] A. Paramita, F. A. Mustika, and N. Farkhatin, "Aplikasi Sistem Pendukung Keputusan 
Guru Terbaik Berdasarkan Kinerja dengan Metode Analytical Hierarchy Process (AHP)," J. Nas. Teknol. Dan Sist. Inf., vol. 3, no. 1, pp. 9-18, 2017.

[7] S. Hidayat and R. Irviani, "Sistem Pendukung Keputusan Pemilihan Guru Teladan Ma Al Mubarok Batu Raja Menggunakan Metode Topsis," J. TAM (Technology Accept. Model., vol. 6, pp. 1-8, 2017.

[8] F. Syakti, "Sistem Informasi Geografis Penderita Malaria pada Kelurahan Cereme Taba Kota Lubuklinggau," Digit. Zo. J. Teknol. Inf. dan Komun., vol. 10, no. 2, pp. 178-188, 2019.

[9] E. W. Guntari, A. S. Permana, and F. R. Umbara, "Prototype Sistem Informasi Eksekutif Dosen di Perguruan Tinggi Swasta ABCD," JUMANJI (Jurnal Masy. Inform. Unjani), vol. 3, no. 02, pp. 53-61, 2020.

[10] M. R. F. Hadi and H. Saputro, "Sistem Informasi Kas Masjid Sebagai Pengaman serta Mempermudah dalam Dokumentasi Aliran Dana," J. Teknol. dan Manaj., vol. 1, no. 1, pp. 40-49, 2020.

[11] G. B. Sulistyo, "Perancangan Sistem Informasi Manajemen Petenakan Sapi Berbasis Online," IJNS-Indonesian J. Netw. Secur., vol. 9, no. 1, 2019.

[12] R. S. Pressman, "Software-Engineering 7th ED by Roger S," Press. Softw. Eng. A Pract. Approach, 2012.

[13] S. Manurung, "Sistem Pendukung Keputusan Pemilihan Guru dan Pegawai Terbaik Menggunakan Metode MOORA," Simetris J. Tek. Mesin, Elektro dan Ilmu Komput., vol. 9, no. 1, pp. 701-706, 2018.

[14] F. Duwiyanti and M. Ardhiansyah, "Sistem Pendukung Keputusan Pemilihan Guru Terbaik di SMK Pustek Serpong Dengan Menggunakan Metode TOPSIS," Int. J. Educ. Sci. Technol. Eng., vol. 2, no. 1, pp. 45-67, 2019.

[15] F. Satria, "Sistem Pendukung Keputusan Penilaian Kinerja Guru Terbaik Pada Min Kedondong Menggunakan AHP (Analytic Hierarchy Process)," J. TAM (Technology Accept. Model., vol. 3, pp. 21-31, 2017.

[16] N. Oktaviani and S. Sauda, "Pemodelan dan Implementasi Aplikasi Mobile Umrah Guide Menggunakan Unified Modeling Language," J. Sains dan Inform., vol. 5, no. 2, pp. 177-186, 2019.

[17] M. J. Siregar, "Rancang model penilaian kinerja karyawan dengan metode 360 degree di departemen warehouse," profisiensi, vol. 6, no. 1, 2018.

[18] D. Gustiana and I. Hariman, "Aplikasi sistem percetakan rapor berdasarkan k-13 dengan menggunakan pendekatan metode 360 derajat di smk handayani banjaran," J. Komput. Bisnis, vol. 12, no. 1, pp. 32-38, 2019.

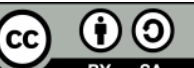

Digital Zone: Jurnal Teknologi Informasi dan Komunikasi is licensed under a Creative Commons Attribution International (CC BY-SA 4.0) 